\title{
Depth cognition of the functional dualism of the individual's psyche
}

\author{
S. O. Manzhara \\ Department of Psychology, Depth Correction and Rehabilitation, Bogdan Khmelnytsky Cherkasy National University, \\ Cherkasy, Ukraine \\ Corresponding author. E-mail: oleshko1008@gmail.com
}

Paper received 03.04.20; Accepted for publication 26.04.20.

\section{https://doi.org/10.31174/SEND-PP2020-227VIII91-14}

\begin{abstract}
The article deals with the phenomenon of dualism in the context of the psyche's integrity with the functional asymmetry and the unity of the conscious and the unconscious, which interact with each other in terms of both antagonism and synergy. The dualism of the psyche's nature is revealed through the following categories: isomorphism vs. homomorphism; the principle of additionality; implicit order; mental defense system. The concept of the study is based on the psychodynamic theory developed by the academician of the National Academy of Pedagogical Sciences of Ukraine T. Yatsenko.
\end{abstract}

Keywords: deep cognition, dualism, the unconscious, psyche, the conscious, psychological defence.

Introduction. According to the «Philosophical Encyclopedic Dictionary», dualism (from Latin. Dualis - double) is «a philosophical doctrine, that proceeds from the recognition of the equal, irreducible to each other of two principles - spirit and matter, ideal and material» $[9, \mathrm{p}$. 178]. This category is used in asserting «the equality of any opposite principles or spheres» [ibid]. In the «Dictionary of Symbols», dualism is defined as: «a system, that assumes a binary model, ... that seeks to resolve it more quickly in synthesis, than by using two opposite principles» [5, p. 187]. Therefore, dualism implies the presence of two distinct but interrelated elements (parts).

A brief overview of publications on the topic. The category of dualism has long been in the field of psychologists' view: W. James and J. Locke considered the Physical and the Mental as a pair of equal but incompatible substances; M. Cuzansky and J. Bruno considered opposites not antagonistic, but those that match; S. Rubinstein, A. Adler, and A. Miletsky emphasized the unity of opposites - parts of one, single substance; S. Freud researched the conscious and the unconscious, instinct «to life» - «to death» and so on.

In the psychodynamic paradigm the problem of the psyche's duality was investigated by such psychologists as: S. Avramchenko (internal contradiction of the psyche), T. Bogdan (correction of internal contradictions by means of psychodrama), T. Nekrut (personal contradictions in persons with LPhC (limited physical capacity)) and N. Sivoplyas (tendencies «to power» and «to weakness»).

The purpose of the article is to reveal the peculiarities of understanding the functional dualism of the conscious and the unconscious.

Materials and methods. The main method of research is the method of active social-psychological cognition (hereafter - ASPC) [10 - 23], which primarily presupposes spontaneity and ease. The ASPC group process involves the introduction of humanistic principles: «here and now»; absence of evaluative judgments, criticism, wishes, black and white categories of «good vs. bad», requirements for any forms of behavior that will be selfevident. Thus, a person, who participates in the ASPC, can feel free without worrying about the level of socialpersonal development, that he or she will be active in.

The psyche in its integrity (the conscious and the unconscious) can be recognized only by the means of visualized representations. A psychologist offers a subject some neutral material for his / her free choice: a complex of thematic psycho-drawings, reproductions of artistic canvases, stones, toys, etc. The filling of self-presenters takes place in a dialogic interaction in the system «Psychologist $\leftrightarrow$ Respondent», due to the symbolism of the subject's psyche and his/her awareness of the functional features of the subject world.

Results and Discussion. The leading characteristic of the psychic is «the focus on equilibrium between competing tendencies, which is characterized by the desire to maintain the optimum, harmony, equilibrium in their interaction. Even the price of deviations from reality is provided by psychological defence through the process of subjective integration of the psyche» [15, p. 38].

The psyche is dual in nature: the spheres of the conscious and the unconscious are functionally diametrically opposite, asymmetric, autonomous and, at the same time, interconnected. All of the mentioned characteristics are taken into account during the psychocorrection process. The conscious and the unconscious - «mutually exclusive and mutually compensating psychic elements within a unified system of relationships, beyond which they cease to be phenomena of the psyche» $[3$, p. 353]. The conscious is dependent on the social requirements of a person, whereas the unconscious is connected with the natural instincts, which often do not meet the societal requirements.

Within the depth psychology, the psyche is considered from three perspectives: dynamic (interaction of mental forces), energy (direction of psychic energy) and structural (hierarchy of psychic substructures).

The structure of the psyche as described by S. Freud reflects the dynamics and the statics of its functioning "vertically». The scientist has distinguished the following components of the psyche: Super-Ego, Ego, Id, which are in the antagonistic confrontation and try to level each other. «Antagonism (from the Greek. - dispute, struggle) - one of the forms of contradictions, characterized by acute irreconcilable struggle of opposing forces, tendencies» $[9$, p. 26]. Classical psychoanalysis sees the confrontation and counteraction between the psyche and the external environment.

The above is reflected in «the Model of internal dynamics of the psyche» (hereafter - Model) (Fig.) [8], developed by the Academician of the National Academy of Pedagogical Sciences of Ukraine T. Yatsenko. It is introduced in the psychodynamic paradigm as 
fundamental for understanding the essence of the psyche. The model (Fig.) illustrates the integrity of the psyche in its dynamic interconnections along «vertical» and «horizontal», reflecting the contradictory unity of the the conscious and the unconscious, coexisting under the laws of isomorphism and homomorphism; symmetry and asymmetry [12].

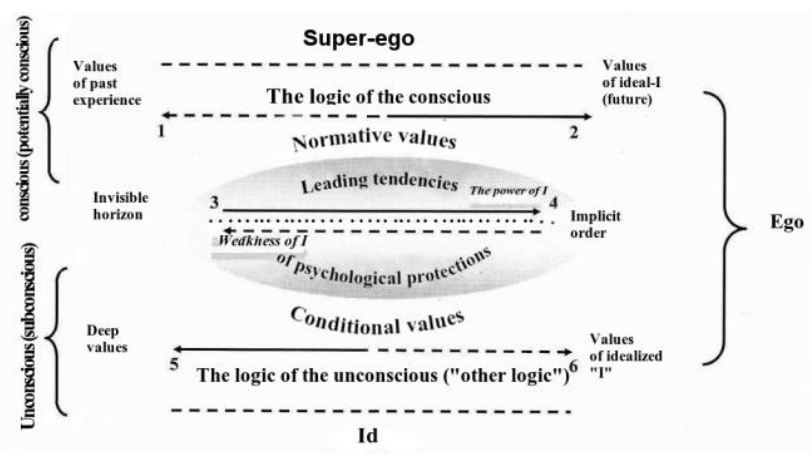

Fig. 1. Model of internal dynamics of the psyche [8, c. 34]

T. Yatsenko supplemented the structure of the psyche, discovered by S. Freud, linearly. The scientist introduced the «horizontal», which describes «the coexistence of contradictions in accordance with the laws of antinomy, which provide both continuation and interchange of one contradictory tendency with another one» [12, p. 110]. The concept of antinomy (from the Greek. - contradiction of the law itself) - «1) is the combination of mutually contradictory statements about the subject which allow equally convincing logical reasoning» [9, p. 28]. Antinomy adequately delineates the complexity of the mental category and the multifaceted interconnections between contradictory in essence substructures.

The dualism of the conscious and the unconscious is objectified through the parameters of isomorphism and homomorphism, which respectively mean «uniformity and similarity of the construction (structure) of systems» [9, p. 202]. Homomorphism and isomorphism exist between systems of different nature: in the conscious everything is discrete, and in the unconscious everything always forms a unity; the conscious is subject to the laws of the material world, while in the unconscious there is neither space, nor time, nor sex; «the conscious "seeks" to be in the objective categories of reality, the unconscious does that in the imaginary, the supposed» [17, p. 422].

Isomorphism «is a relation of the type of equality» $[9$, p. 203], that is, identity, correlation with a particular element. The unconscious ensures its diversity of manifestations in the human behavior by the homomorphic interconnection between the unconscious and the conscious. On the one hand, there is an identity (isomorphism) between the conscious and the unconscious, because they are involved in one reality. On the other hand, one deep root cause of the unconscious is latently manifested in many variants of manifestations of the conscious behavior (homomorphism). Each determinant catalyzes behavior variations, hidden and unrecognized unless studied. Present in the act of conscious behavior, but at the latent level.

In the subject's behavior isomorphism turns into homomorphism, since «any isomorphism is a homomorphism, but not vice versa» [9, p. 203]. That is, one unconscious cause is manifested by many conscious (behavioral) acts. Therefore, in the diagnostic-correction work there is a variety of forms of projection involved: drawing, stones, toys, verbal text, etc.

The dualism of the psyche, as shown by the results of the psychodynamic research, integrates in an implicit order, where the conscious and the unconscious merge. Introduced by T. Yatsenko, the category «implicit order» $[14 ; 21-23]$ expresses the integrity of the psychic, integrates the force fields of belonging of the conscious and the unconscious, regardless of their functional asymmetry. The implicit order is «invisible and externally uncontrolled order of spontaneous manifestations of a respondent's activity» [23]. Functionally, it correlates with the «invisible horizon» (a term borrowed from S. Hawking to denote a neutral zone between the conscious and the unconscious). The above categories completed "The model of internal dynamics of the psyche» by T. Yatsenko (see middle of Fig.).

The central link in the Model (Fig.) is the psychological defence, which «can be conditionally called the integration unit, the substructure of the psyche that synthesizes the vertical (Super-Ego, Ego, Id) and the horizontal (vector)» [15, p. 50]. Invisible, elusive defenses serve as a connecting link, «the "royal path", which opens up the possibilities of knowing the relationship between the unconscious and the conscious, the two opposites, that are in antinomy» [16, p. 104]. The dualism of the defence system presupposes the encompassing of functionally asymmetric spheres of the conscious and the unconscious.

Psychological defences were investigated by F. Basin, O. Bodalev, F. Vasiliuk, A. Dreyer, Y. Kolominsky, B. Parigin, F. Fox, A. Freud, S. Freud, and B. Furst. The research of the defence system in the psychodynamic paradigm was carried out by: T. Gorobets (socioperceptual deformations), V. Konovalchuk (mechanism of substitution), S. Rajabova (mechanism of identification), O. Svyatka (phenomenon of resistance), N. Shavrovska (genesis of defences in psychodynamic paradigm). T. Yatsenko distinguished two types of psychological defenses: basal («horizontal») and situational, peripheral («vertical») [10], which, in their turn, integrate the mechanisms of defence introduced by S. Freud and A. Freud.

The defense system is subject to a single general mechanism «from weakness to strength». This is their manifestation of prosocial origin: if there were no society, there would be no protection in the paradoxical forms in which they exist. Psychological defences play a wrongintegrating role: they include the phenomenon of mental reality, which creates the illusion of psychic integrity of the subject [17].

The defences are generated by «two reasons: the desire to satisfy the needs "for strength" by means of the infantile Self in accordance with the deep values (the basis of which is laid in the oedipal period) and to create the illusion of their compliance with prosocial requirements (declared by Super-Ego)» [15, p. 38]. So, psychological defences save Self «from the dissonance (disharmony) that, on the one hand, is stimulated by the imperativeness of Id instincts and their inappropriateness to social constraints, and on the other hand, it is 
stimulated by the need to focus efforts of Self on prosocial orientation, on success» [ibid].

Defences play a dual role: from one side, they adapt to the demands of the society, whereas from the other side, they do not lose sight of the interests given by Id, indirectly represented in the subconscious. They integrate the psyche (on a imaginary-illusory basis) and, at the same time, disintegrate by deviations from reality, creating preconditions for stabilizing internal contradictions.

Deep cognition is aimed at the study of the psyche in its integrity, provided by the introduction of principle of additionality [13 - 14], borrowed in quantum physics (N. Bohr) and researched by the Georgian psychologist A. Sherozia [3]. In the process of exploring the psyche, the principle of additionality determines the need to take into account both of its spheres, it «... concerns realities that differ in functional contradiction and incompatibility, but at the same time, have the prospects of studying them in their entirety» $[13$, p. 12]. The principle of additionality is introduced in the form of two principles $[13 ; 14]$ : the first one is «the inseparability of the conscious and the unconscious», which relates to the nature of the mental in its integrity, and the seond one is «from the other», which consists in the professionalism of the psychologist to ask questions, which stimulate interaction with the respondent.

The principle of inseparability indicates, that optimal cognition of the holistic psyche requires attention to both spheres (the conscious / the unconscious), which are functionally interdependent and, at the same time, autonomous. T. Yatsenko emphasizes, that «the two spheres of the psyche are not only interconnected, but also indirectly involved in the very process of formation of one or another sphere» [13, p. 13]. Therefore, the principle of inseparability attests to the implicit activity of two spheres (the conscious / the unconscious) in each act of the subject's behavior.

The «from the other» principle sets forth the methodological foundations, whihc «determine the unconscious, in synthesis with the conscious, in the act of spontaneous activity of the subject. It embodies the prerequisites for optimizing the diagnostic-correction process at the boundary of the involvement of the spheres of the conscious and the unconscious» $[13, \mathrm{p}$. 17]. This principle reveals the way of methodological implementation of the principle of additionality, which determines the specificity of the construction of deep cognition. The psychologist should ask respondents the questions which would catalyze the impulse from the unconscious («pull from another»).

Conclusions. Nature dualism, human dualism in particular, was the subject of interest for philosophers and psychologists of different eras and nations. The current research acievements assert, that the human psyche is dual, i.e. it has two spheres: the conscious and the unconscious, which are in a constant dynamic unity of the complementarity and continuous struggle. The latter ultimately seeks harmony and balance. The dualism of the psyche is provided by the structural and functional parameters by which they exist: antagonism and antinomy; isomorphism and homomorphism; psychological defence; implicit order; principle of additionality, etc. Along with numerous studies of the conscious and the unconscious spheres, the essence of the psyche's duality deserves careful further study.

\section{ЛИТЕРАТУРА}

1. Агрессия: психологическая теория и феноменология / Т. С. Яценко, А. В. Глузман, А. Э. Мелоян, Л. Г. Туз ; [под ред. акад. НАПН Украины Т. С. Яценко]. - Киев : Вища шк., 2010. - 271 с.: ил.

2. Андрущенко В. П., Яценко Т. С. Філософія і психологія психодинамічного пізнання / Т. С. Яценко // Психологічне консультування i психотерапія. - 2015. - Т. 2, № 1-2. - С. 6 - 26. - Режим доступу: http://nbuv.gov.ua/UJRN/pscp_2015_2_1-2_3.

3. Бассин Ф. В. Прагнишвили А. Г., Шерозия А. Е. Бессознательное. Природа. Функции. Методы исследования. В 4-х т. Т. 3. - Тбилиси, 1978. - 800 с.

4. Блейхер В. М., Крук И. В. Толковый словарь психиатрических терминов. - Воронеж: НПО «МОДЭК», 1995. $-640 \mathrm{c}$.

5. Керлот Х. Э. Словарь символов. - М.: «REFL-book», 1994. -608 c.

6. Концептуальні засади і методика глибинної психокорекції: Підготовка психолога-практика: Навч. посіб. / Т. С. Яценко, Б. Б. Іваненко, С. М. Аврамченко та ін.; За ред. Т. С. Яценко. - К.: Вища шк., 2008. - 342 с.: іл.

7. Лапланш Ж., Понталис Ж.-Б. Словарь по психоанализу. М.: Высшая школа, 1996. - 623 с.

8. Наукова школа академіка НАПН України Тамари Яценко: колективна монографія / за заг. ред. акад. Т. С. Яценко. Дніпро : Інновація, 2019. - 350 с.

9. Философский энциклопедический словарь / Гл. редакция: Л. Ф. Ильичёв, П. Н. Федосеев, С. М. Ковалёв, В. Г. Панов. - М.: Советская энциклопедия, 1983. - 840 с.

10. Яценко Т. С. Психологические основы активной подготовки будущего педагога к общению с учащимися :

дис. ... докт. психол. наук : спец. 19.00.07. «Педагогическая и возрастная психология» / Т. С. Яценко - К., 1989. -432 c.

11. Яценко Т. С. Психологічні основи групової психокорекції : навчальний посібник / Т. С. Яценко. Київ : Либідь, 1996. - 264 с.

12. Яценко Т. С., Глузман А. В. Методология глубиннокоррекционной подготовки психолога / Т. С. Яценко, А. В. Глузман. - Днепропетровск: Изд-во «Инновация», 2015. $-396 \mathrm{c}$.

13. Яценко Т. С. Динамика развития глубинной психокоррекции: теория и практика : монография / T. С. Яценко. - Днепропетровск : Инновация, 2015. - 567 c.

14. Яценко Т. С. Категорії «принцип додатковості» та «імпліцитний порядок» в глибинному пізнанні психіки / T. С. Яценко // Науковий теоретико-методологічний i прикладний психологічний журнал «Психологія особистості». - № 1 (8). - 2017. - С. 15-23.

15. Яценко Т. С. Компроміс свідомого і несвідомого в контексті проблеми адаптації суб'єкта. Психологічне консультування i психотерапія, № 1-2. Харківський національний університет імені В. Н. Каразіна. - 2014. C. 37-52.

16. Яценко Т. С. Особливості взаємозв'язків між свідомою та несвідомою сферами психіки суб'єкта. Неперервна освіта: теорія і практика // Науково-методичний журнал. - 2002. - Випуск 5 (8). - С. 99-110.

17. Яценко Т. С. Новий підхід до пізнання психічного в його внутрішній динаміці // Актуальні проблеми сучасної української психології: Наукові записки Інституту 
психології ім. Г. С. Костюка АПН України. - К., НораДрук, 2003. - Вип. 23. - С. 419-433. корекція тенденції до психологічної смерті : [навч. посіб.] / Т. С. Яценко, О. В. Глузман, І. В. Калашник. - Ялта : РВВ КГУ, 2008. - 204 с.

19. Яценко Т. С. Глибинне пізнання самодепривації психіки майбутнього психолога / Т. С. Яценко, В. І. Бондар. - К. : НПУ імені М. П. Драгоманова, 2016. - 383 с.

20. Яценко Т. С. Самодепривація психіки та дезадаптація суб' єкта : монографія / [Т. С. Яценко та ін.]. - Київ : Видво НПУ ім. М. Драгоманова, 2015. - 280 с.

21. Yatsenko T. S. «Implicit order» as a form of manifestation
18. Яценко Т. С. Глибинна психологія: діагностика та

the contradictory nature of the psychic integrity / T. Yacenko // American Journal of Fundamental, Applied and Fundamental Research. - 2017. - № 3. - P. 93-111.

22. Яценко Т. C. Implicit order and functional efficiency in the deep knowledge of the psyche [Імпліцитний порядок та його функціональна дієвість в глибинному пізнанні психіки] Fundamental and applied researches in practice of leading scientific schools. - 2018. - № 25 (1). - C. 23-37.

23. Yatsenko T. S. The phenomenon of «implicit order» of indepth cognition of the psyche / T.S. Yatsenko // Technologies of intellect development. - $2017-$ Vol. 2. №5.

\section{REFERENCES}

1. Aggression: psychological theory and phenomenology / T. S. Yatsenko, A. V. Hluzman, A. E. Meloian, L. H. Tuz ; [ed. Acad. NAPS of Ukraine T. S. Yatsenko]. - Kiev: Vishcha School, 2010. - 271 p.: ill.

2. Andrushchenko V. P., Yatsenko T. S. Philosophy and psychology of psychodynamic cognition / V. P. Andrushchenko, T. S. Yatsenko // Psychological counseling and psychotherapy. - 2015. - Vol. 2, № 1-2. - P. $62-26 . \quad-\quad$ Access mode: http://nbuv.gov.ua/UJRN/pscp_2015_2_1-2_3.

3. Bassin F. V. Pragishvili A. G., Sherosia A. E. The Unconscious. Nature. Functions. Research methods. In 4 volumes T. 3. - Tbilisi, 1978. -800 p.

4. Bleicher V. M., Kruk I. V. The intelligent dictionary of psychiatric terms. - Voronezh: MODEC NGO, 1995. - 640 p.

5. Carlot H.E. Character Dictionary. - M.: «REFL-book», 1994. $-608 \mathrm{p}$.

6. Conceptual foundations and methodology of deep psychocorrection: Training of psychologist-practitioner: Educ. tool. / T. S. Yatsenko, B. B. Ivanenko, S. M. Avramchenko and others; Edited T. S. Yatsenko. - K.: Vishcha School, 2008. 342 p.: ill.

7. Laplanche J., Pontalis J.-B. Dictionary of psychoanalysis. M.: Vishcha School, 1996. - 623 p.

8. Scientific school of the NAPS's of Ukraine academician Tamara Yatsenko: a collective monograph / by head. ed. acad. T. S. Yatsenko. - Dnipro: Innovation, 2019. - 350 p.

9. Philosophical Encyclopedic Dictionary / Ch. Edition: L. F. Ilyichev, P. N. Fedoseev, S. M. Kovalev, V. G. Panov. - M .: Soviet Encyclopedia, 1983. - 840 p.

10. Yatsenko T. S. Psychological foundations of the active preparation of the future teacher to communicate with students: dis. ... doc. psychol. sciences: special. 19.00.07. "Pedagogical and developmental psychology" / T. S. Yatsenko - K., 1989. - 432 p.

11. Yatsenko T. S. Psychological foundations of group psychocorrection: a textbook / T. S. Yatsenko. - Kiev: Libid, 1996. $-264 \mathrm{p}$.

12. Yatsenko T. S., Gluzman A. V. Methodology of deep correc- tion training of a psychologist / T. S. Yatsenko, A. V. Gluzman. - Dnepropetrovsk: Innovation, 2015. - 396 p.

13. Yatsenko T. S. Dynamics of development of deep psychocorrection: theory and practice: monograph / T. S. Yatsenko. - Dnepropetrovsk: Innovation, 2015. - 567 p.

14. Yatsenko T. S. The categories "principle of additionality» and «implicit order» in the deep cognition of the psyche / T. S. Yatsenko // Scientific theoretical-methodological and applied psychological journal «Psychology of personality». № 1 (8). - 2017. - P. 15-23.

15. Yatsenko T. S. A compromise of the conscious and the unconscious in the context of the problem of adaptation of the subject. Psychological Counseling and Psychotherapy, №. 12. V. N. Karazin Kharkiv National University. - 2014. - P. 37-52.

16. Yatsenko T. S. Features of interrelations between the conscious and unconscious spheres of the subject's psyche. Continuing Education: Theory and Practice // Scientific and Methodical Journal. - 2002. - Volume 5 (8). - P. 99-110.

17. Yatsenko T. S. A new approach to the cognition of the psychic in its internal dynamics // Actual problems of modern Ukrainian psychology: Scientific Notes of the Institute of Psychology. G. S. Kostyuk APS of Ukraine. - K., Nora-Print, 2003. - Vol. 23. - P. 419-433.

18. Yatsenko T. S. Deep psychology: diagnosis and correction of the tendency to psychological death: [textbook]. tool.] / T. S. Yatsenko, O. V. Gluzman, I. V. Kalashnik. - Yalta: RVV of KSU, 2008. - 204 p.

19. Yatsenko T. S. Deep cognition of psyche's self-deprivation of the future psychologist / T. S. Yatsenko, V. I. Bondar. K.: N. P. Drahomanov, 2016. -383 p.

20. Yatsenko T. S. Self-deprivation of the psyche and maladaptation of the subject: monograph / [T. S. Yatsenko and others]. - Kiev: Publishing House of the NPU M. Drahomanov, 2015. - 280 p.

22. Yatsenko T. S. Implicit order and functional efficiency in the deep knowledge of the psyche Fundamental and applied researches in practice of leading scientific schools. - 2018. № 25 (1). - C. 23-37. 